\title{
Estudo farmacobotânico de partes aéreas vegetativas de aroeira-vermelha (Schinus terebinthifolius Raddi, Anacardiaceae)
}

\author{
AZEVEDO, C.F."; ;UIRINO, Z.G.M.2; BRUNO, R.L.A.'1 \\ 'Universidade Federal da Paraíba, Centro de Ciências Agrárias, Campus II, 58397-000, Areia-Paraíba-Brasil, \\ E-mail: camfiraze@bol.com.br 2Universidade Federal da Paraíba, Centro de Ciências Aplicadas e Educação, \\ Campus IV, 52280-000, Mamanguape-Paraíba-Brasil.
}

\begin{abstract}
RESUMO: Schinus terebinthifolius Raddi (Anacardiaceae), conhecida como aroeira-vermelha é uma espécie nativa do Brasil, perenifólia e pioneira, sendo muito utilizada para combater diversas doenças, pois apresenta, entre outras, propriedades anti-inflamatórias e cicatrizantes. O objetivo desta pesquisa foi realizar um estudo morfoanatomico do caule e da folha de $S$. terebinthifolius, descrevendo a organização dos tecidos e suas possíveis variações. As análises macro e microscópicas foram realizadas com material selecionado de partes vegetativas de um espécime localizado na cidade de Campina Grande - PB. A aroeira-vermelha é um vegetal arbóreo e dióico, que apresenta caule cilíndrico e simpodial, com casca rugosa e estriada. A folha é perene, alterna, coriácea e composta. As análises microscópicas evidenciaram epiderme caulinar e foliar uniestratificadas, exceto na face adaxial da folha, que é bisseriada. No caule e no pecíolo são visualizados muitos tricomas tectores unicelulares, curtos, cônicos e agudos no ápice. Encontram-se canais secretores arredondados e bem desenvolvidos na região do floema em todos os órgãos estudados, bem como cutícula revestindo as células epidérmicas e grande quantidade de drusas de oxalato de cálcio. Os feixes vasculares são circundados por células esclerenquimáticas e apresentam o floema seguido por xilema helicoidal bem desenvolvido. No caule, pecíolo e nervura central da folha, o xilema é interno e o floema, externo. A aroeira-vermelha apresenta alguns aspectos estruturais característicos de plantas xerófilas, como camada múltipla da epiderme da face adaxial foliar, que protegem o mesofilo de excessiva dessecação; presença de cutícula espessa e grande quantidade de pêlos e de estômatos; além de sistema vascular bem desenvolvido, com abundância de esclerênquima, dando sustentação ao feixe.
\end{abstract}

Palavras-chave: Schinus terebinthifolius, Anacardiaceae, canais secretores, caule, folha, morfoanatomia, drusas de oxalato de cálcio.

\begin{abstract}
Pharmacobotanical study of the aerial parts of Brazilian pepper (Schinus terebinthifolius Raddi). Schinus terebinthifolius Raddi (Anacardiaceae), popularly known as Brazilian pepper, is an evergreen, pioneer and indigenous plant from Brazil, and it is used to combat various diseases, as it presents anti-inflammatory and wound healing properties. The aim of this research was to study the morpho-anatomical features of the stem and leaf of $S$. terebinthifolius, describing the organization of the tissues and their variations. The macroscopic and microscopic analyses were performed with material selected from vegetative parts of a specimen collected in the city of Campina Grande - state of Paraíba, Brazil. The Brazilian pepper is a dioecious plant with cylindrical and sympodial stem and rough and striated bark. The leaves are evergreen, alternate, leathery and compound. The microscopic analysis showed uniseriate epidermis in the stem and leaf, except in the adaxial leaf, which is biseriate. In the stem and petiole, many unicellular, short, conical tector trichomes with acute apex are observed. In the phloem of all studied organs, we found rounded and well-developed secretory ducts, as well as cuticle covering the epidermal cells and a large amount of calcium oxalate druses. The vascular bundles are surrounded by sclerenchyma cells and present phloem followed by well-developed spiral xylem. In the stem, petiole and leaf's central vein, the xylem is internal and the phloem is external. The Brazilian pepper has some structural features characteristic of xerophilous plants, such as multiple layers of the epidermis in adaxial leaf, which protects the mesophyll from excessive drying, thick cuticle and a large quantity of hairs and stomata, well-developed vascular system with plenty of sclerenchyma, giving support to the bundle.
\end{abstract}

Key words: Schinus terebinthifolius, Anacardiaceae, morphoanatomy, leaf, secretory ducts, stem, calcium oxalate druses. 


\section{INTRODUÇÃO}

Existem várias espécies de plantas medicinais conhecidas, sendo utilizadas popularmente para combater vários tipos de doenças. Dados da Organização Mundial da Saúde (OMS) mostram que cerca de $80 \%$ da população mundial já fizeram uso de algum tipo de erva na busca do alívio de alguma enfermidade (Martins et al., 2000). Porém, por se tratarem de produtos ainda pouco estudados, as plantas medicinais precisam passar por muitas pesquisas, o que tem propiciado avanços importantes para o tratamento de várias patologias, originando medicamentos eficientes e com menores custos.

Entre as espécies medicinais nativas do Brasil, tem-se Schinus terebinthifolius Raddi (Anacardiaceae), conhecida como aroeira-vermelha e aroeira-pimenteira, principalmente pela aparência de seus frutos e por ser usado como condimento alimentar. De acordo com Lorenzi \& Matos (2008) e Amorim \& Santos (2003), as cascas do caule são utilizadas para combater inflamações de várias origens, principalmente as do sistema genital feminino, pois apresentam, entre outras, propriedades anti-inflamatórias e cicatrizantes. Além das suas propriedades medicinais, esse vegetal é comumente usado na arborização de ruas e praças e na produção de lenha e carvão. A madeira é bastante resistente, sendo usada como cercas vivas, além de ser uma das espécies mais procuradas pela avifauna (Carmello-Guerreiro \& Paoli, 2002).

Vários metabólitos secundários já foram identificados em S. terebinthifolius, a exemplo de alcaloides (Ceruks et al., 2007) e terpenos (Malik et al., 1994). Barbosa e colaboradores (2007) determinaram os sesquiterpenos como substâncias presentes em maior quantidade nas folhas. Santos e colaboradores (2013) identificaram 37 constituintes químicos no óleo essencial; os principais foram germacreno $D(25,0 \%),(E)$ - $\beta$-cariofileno $(17,5 \%)$ e $\delta$-elemeno (10,5\%). Além destes, também foram observados $\alpha$-pineno (Matsuo et al., 2011) e limoneno (Santos et al., 2007). Estudos recentes comprovaram atividade antimicrobiana (Degáspari et al., 2005; Johann et al., 2008; Paiva et al., 2010; Machado et al., 2012; Gomes et al., 2013), antiinflamatória (Medeiros et al., 2007; Varela-Barca et al., 2007), antifúngica (Fenner et al., 2006; Santos et al., 2010; Khan, 2013), antitumoral (Queires et al., 2013) e inseticida (Santos et al., 2013) dessa espécie.

Este trabalho representa importante caracterização morfoanatômica de S. terebinthifolius que, por muitas vezes, é confundida com outras espécies do mesmo gênero (Schinus) e até da mesma família; como exemplos têm-se os gêneros Lithraea e Astronium que, segundo Queiroz e colaboradores (2002), também incluem espécies conhecidas popularmente como aroeira. No Brasil, essas espécies apresentam, muitas vezes, diversos aspectos semelhantes, além da existência de muitas variedades, as quais podem ser enquadradas como sinônimas na classificação taxonômica. A identificação correta das plantas medicinais é de fundamental importância para garantir o uso seguro, uma vez que os nomes vulgares das plantas variam de acordo com a região.

Mesmo apresentando grande potencial medicinal, ecológico e madeireiro, poucas pesquisas foram realizadas com enfoque morfológico e anatômico com a aroeira-vermelha, existindo trabalhos que enfatizam principalmente o fruto e a biologia reprodutiva, fato que serviu de estímulo para o desenvolvimento deste trabalho.

Dessa forma, o objetivo desta pesquisa foi realizar um estudo morfoanatômico do caule e da folha de S. terebinthifolius, descrevendo a organização dos tecidos e suas possíveis variações.

\section{MATERIAL E MÉTODOS}

Foram coletadas partes vegetativas de $S$. terebinthifolius Raddi de um espécime localizado na cidade de Campina Grande, área de agreste Paraibano. Os estudos foram realizados no laboratório de Botânica, do Departamento de Biologia da Universidade Estadual da Paraíba. As análises microscópicas e macroscópicas foram realizadas com material fresco.

Partes vegetativas da planta foram selecionadas aleatoriamente para análises posteriores em laboratório através de observação direta e de esteriomicroscópio, além de câmera fotográfica digital e desenhos esquemáticos para análise e representação dos órgãos.

A medição dos órgãos foi feita com paquímetro digital e o tamanho da folha e do folíolo foi dado pela média de 30 medições, sendo que o folíolo usado foi sempre o do segundo nó. Para a contagem das nervuras, também foram utilizados 30 folíolos, sempre do segundo nó da folha. Foi feita uma média do número de nervuras secundárias e uma média do número de nervuras terciárias encontradas na quinta nervura secundária de cada folíolo.

O material selecionado foi seccionado à mão livre com lâmina cortante, utilizando-se pecíolo de imbaúba como suporte. Utilizou-se hipoclorito de sódio a $1 \%$ para descolorir as secções e posteriormente safranina a $10 \%$ para a coloração. Após este procedimento, o material foi montado em lâminas semipermanentes e analisado em microscópio binocular. 
Para análise da nervura primária da folha, foram feitas secções transversais de pequenas porções retiradas entre a quarta e a quinta nervura secundárias. Para a observação da nervura secundária foi utilizada uma pequena parte da região mediana da quinta nervura. As secções paradérmicas da face abaxial e da face adaxial da folha foram feitas com material retirado na região mediana entre a quarta e a quinta nervuras secundárias. A contagem dos estômatos foi realizada utilizando-se secções paradérmicas da face abaxial da folha e tendo como base $1 \mathrm{~mm}^{2}$.

\section{RESULTADO E DISCUSSÃO}

Schinus terebinthifolius Raddi é uma árvore de 5-7 metros, com caule cilíndrico, aéreo e lenhoso, apresentando ramificação simpodial. Sua casca é rugosa, com estrias longitudinais e cor marrom acinzentada (Fig. 1a).

As folhas são perenes, possui coloração esverdeada, forte aroma e filotaxia alterna. Elas são compostas imparipenadas, com ráquis principal, apresentando pecíolo médio (Fig. 1b). O limbo apresenta forma elíptica, consistência coriácea e bordos pouco ondeados. Na face adaxial não são encontrados tricomas, que se apresentam em quantidade moderada na face abaxial. Do pecíolo até o último folíolo, têm-se $11-15 \mathrm{~cm}$, já o folíolo apresenta de 4-8 cm. A nervação é peninerva (Fig. 1b) e em cada folíolo são encontradas uma nervura central, 15-19 nervuras secundárias e 5-9 nervuras terciárias (em cada nervura secundária). Souza
(2003) denomina esse sistema de venação reticulada, que apresenta nervura central proeminente na face inferior com redes progressivamente menores. Lorenzi (2008) e Barroso \& colaboradores (2004) descreveram caracteres morfológicos foliares para Anacardiaceae semelhantes aos encontrados na aroeira-vermelha, como folhas compostas, alternas e sem estípulas.

O caule jovem de $S$. terebinthifolius em desenvolvimento secundário tem contorno circular um pouco ondeado, acompanhando o desenvolvimento dos feixes vasculares (Fig. 2). Em secção transversal, apresenta epiderme uniestratificada com células variando de quadradas a retangulares e cutícula externa (Fig. 3a). Observase uma grande quantidade de tricomas tectores unicelulares, curtos, cônicos e agudos no ápice (Fig. 3a).

No córtex é visualizado o parênquima cortical, constituído por 1-2 camadas de células parenquimáticas isodiamétricas situadas abaixo da epiderme; e mais internamente, aproximadamente 4-5 camadas de parênquima clorofiliano contínuo (clorênquima). Para Esau (1998), esse tecido está geralmente na periferia do caule, podendo inclusive realizar fotossíntese. Abaixo do parênquima clorofiliano, têm-se 4-6 faixas de colênquima angular, que circundam todo o cilindro central. São encontradas drusas em forma de cristais por todo o parênquima cortical, porém no parênquima clorofiliano está em maior quantidade. Duarte et al. (2009) identificou oxalato de cálcio como material componente das drusas presentes em $S$. terebinthifolius. Esse tipo de drusas também ocorre
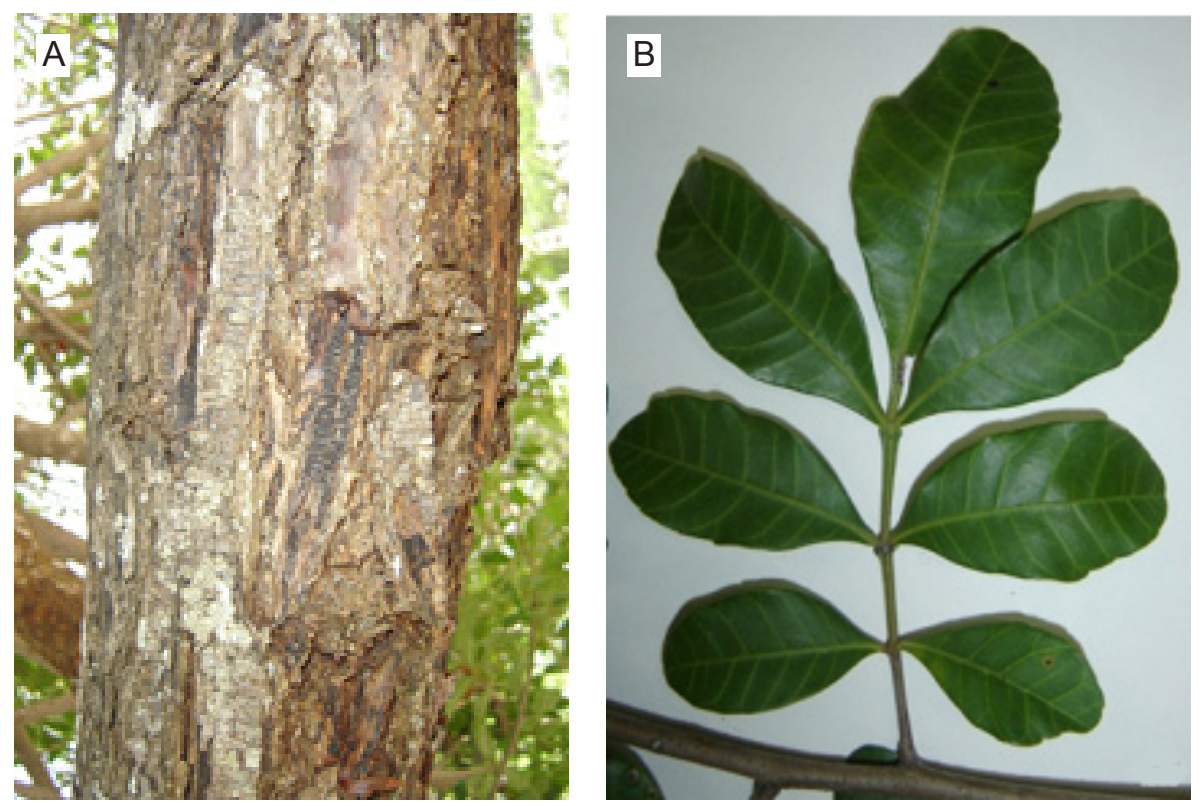

FIGURA 1. Schinus terebinthifolius Raddi, Anacardiaceae. a. Vista geral do caule com estrias longitudinais. b. folha composta. 


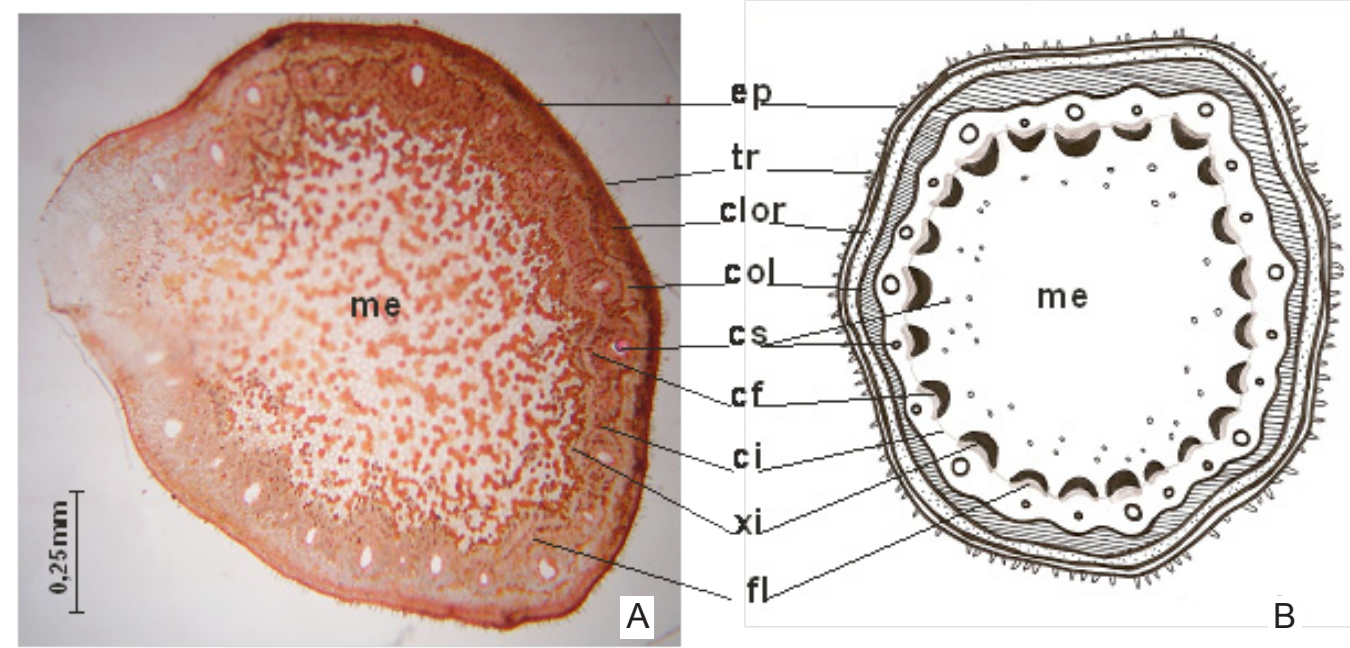

FIGURA 2. Aspecto geral do caule de Schinus terebinthifolius Raddi, Anacardiaceae, em secção transversal. a. fotomicrografia; b. esquema da organização do caule. (me) medula; (ep) epiderme; (tr) tricoma; (clor) clorênquima; (col) colênquima; (cs) canal secretor; (cf) câmbio fascicular; (ci) câmbio interfascicular; (xi) xilema; (fl) floema.
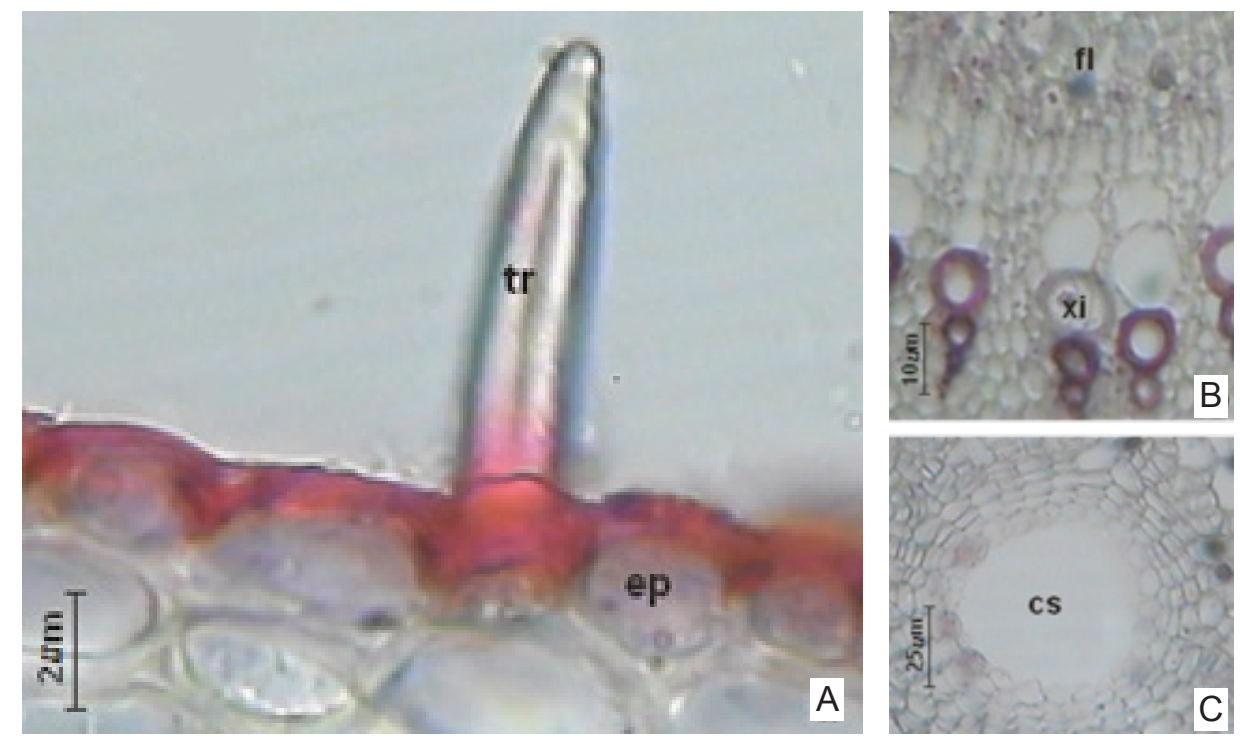

FIGURA 3. Secções transversais do caule de Schinus terebinthifolius Raddi, Anacardiaceae. a. epiderme uniestrataficada e tricoma. b. organização dos tecidos xilema e floema. c. organização do canal secretor demonstrando células achatadas e células epidérmicas que delimitam o canal. (cut) cutícula; (ep) epiderme; (tr) tricoma; (cs) canal secretor; (fl) floema; (xi) xilema.

no fruto da mesma espécie, como afirma CarmelloGuerreiro \& Paoli (1999), podendo apresentar várias formas e tamanhos (Apezzatto-da-Gloria \& Carmello-Guerreiro, 2003) e são comuns quando o cálcio está presente numa concentração muito alta no solo (Dickison, 2000), o que acontece geralmente em ambientes secos. Larrosa \& Duarte (2005) ressaltam que as drusas são úteis como suporte estrutural, proteção contra herbívoros e manutenção do balanço iônico.

Delimitando o córtex, existe uma camada de células parenquimáticas contendo amiloplastos, constituindo a bainha amilífera. São encontradas células esclerenquimáticas distribuídas irregularmente e circundando os feixes vasculares. $\mathrm{Na}$ região do floema de cada feixe vascular, são encontradas 2-4 camadas de células levemente achatadas circundando um canal secretor largo e circular, que é delimitado por células arredondadas um pouco maiores que as células adjacentes. Próximo a esses canais, podem ser encontrados, ocasionalmente, drusas de oxalato de cálcio, inclusive nas células que delimitam o canal (Fig. 3c).

O tipo de canal secretor encontrado na espécie, foi explicado por Esau (1998) como canal esquizógeno, por ser resultante da separação de 
células e são comumente encontrados em coníferas e dicotiledôneas lenhosas. A estrutura do canal secretor encontrado no caule é semelhante ao descrito por Machado \& Carmello-Guerreiro (2001) para os canais encontrados nos frutos da mesma espécie, que apresentam duas a três camadas de células parenquimáticas achatadas e menores que as epiteliais, que circundam cada cavidade. Canais secretores bem desenvolvidos também são encontrados em outras anacardiáceas, como por exemplo Lithraea molleoides (Vell.) Engl. (CarmelloGuerreiro \& Paoli, 2005), Tapirira guianensis Aubl., Spondias dulcis Forst. (Lacchia \& CarmelloGuerreiro, 2009), Astronium graveolens Jacq. (Carmello-Guerreiro \& Paoli, 2000) e Semecarpus anacardium L. (Bhatt \& Mohan-Ram, 1992), que apresentam células epiteliais delimitando o lúmen do canal secretor preenchido por secreção. Os canais secretam produtos de composição química variada, a exemplos de água, soluções salinas, óleos, mucilagens, gomas, proteínas, resinas, entre outros; a natureza do material depende da espécie e do local de crescimento da planta (Fahn, 2000).
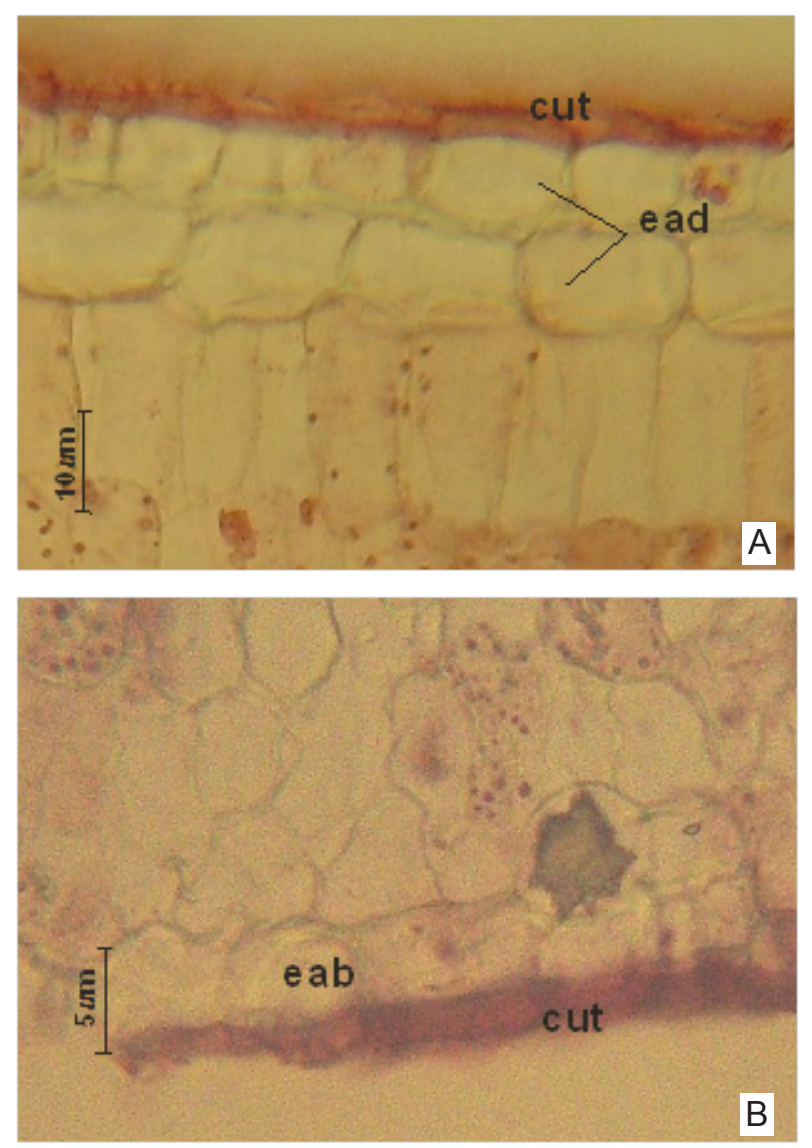

Posteriormente, em cada feixe vascular, encontra-se o câmbio fascicular. Alternadamente aos feixes vasculares são encontrados: parênquima interfascicular estreito, disposto em fileiras, e câmbio interfascicular (Fig. 2). As células cambiais formam floema secundário em direção ao lado externo do caule e xilema secundário em direção ao lado interno. Após o floema, são encontrados, mais internamente, protoxilema e metaxilema, onde os elementos traqueais distribuem-se em fileiras, sendo que existem feixes de células de parênquima alternando-se a eles. O número de raios xilemáticos é variável, notando-se que são encontrados em maior quantidade, geralmente 7-10, quando o feixe vascular está mais desenvolvido. Na região interior aos feixes vasculares também são encontrados canais secretores, dispostos irregularmente, porém são menores que os situados na região do floema. A região medular, muito desenvolvida, possui parênquima com células relativamente grandes $\mathrm{e}$ com paredes delgadas (Fig. 2).

A face adaxial da lâmina foliar apresenta epiderme bisseriada formada por células de
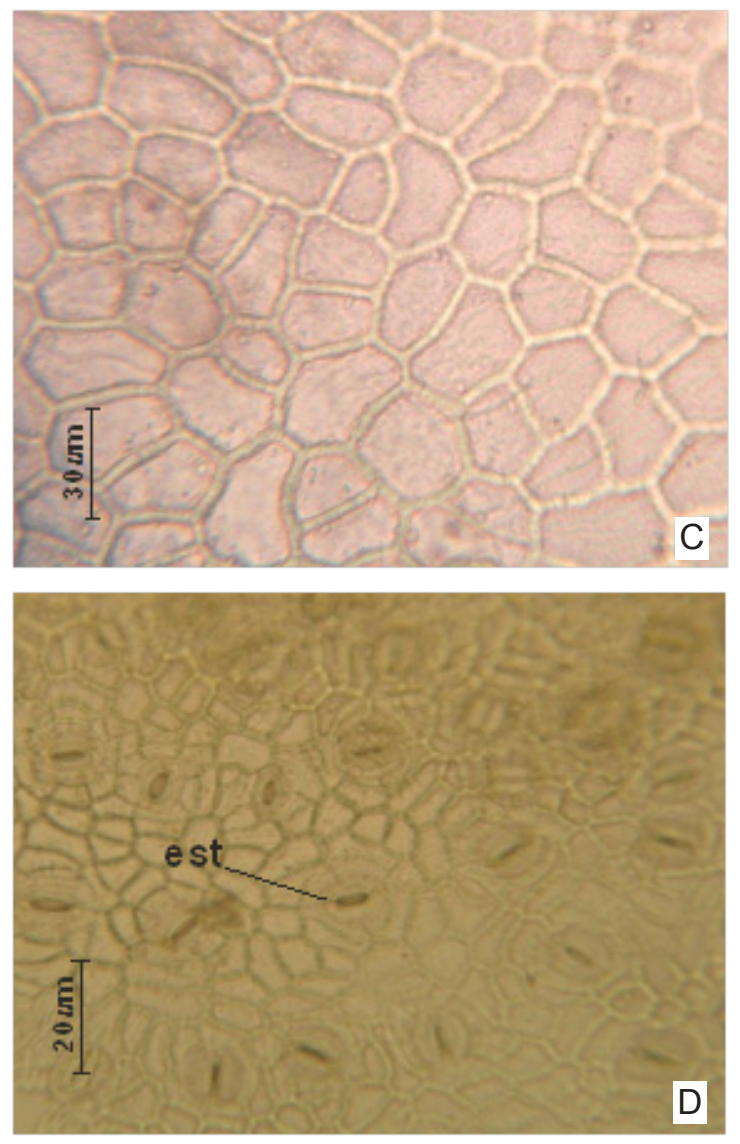

FIGURA 4. Schinus terebinthifolius Raddi, Anacardiaceae. Folha. a. Secções transversais da lâmina foliar demonstrando epiderme adaxial bisseriada coberta por cutícula. b. Secção transversal da lâmina foliar demonstrando drusa e epiderme abaxial unisseriada com cutícula externa. c. células de tamanhos e formas irregulares da epiderme adaxial em secção paradérmica. d. secção paradérmica evidenciando estômatos na epiderme abaxial. (cut) cutícula; (ead) epiderme adaxial; (eab) epiderme abaxial; (est) estômato; (dru) drusa. 
formato irregular (Fig. 4a e 4c), diferentemente de Myracrodruon urundeuva Allemão, que possui epiderme da face adaxial unisseriada (Duarte et al., 2009). Já na face abaxial, a epiderme é estriada, com apenas uma camada de células isodiamétricas (Fig. 4b e 4d), onde são encontrados tricomas nãoglandulares unicelulares e tricomas glandulares com atividade secretora, apresentando, em sua maioria, 3-6 células (Fig. 5a, b e c). Estrias na epiderme é uma condição que potencializa a captação de luz (Taiz \& Zeiger, 2009) e, além disso, MoreiraConeglian \& Oliveira (2006) afirmam que as células epidérmicas com estrias apresentam aumento da superfície de contato entre células, ampliando a resistência do sistema dérmico e sua eficiência na transferência de substâncias célula a célula. As epidermes abaxial e adaxial são revestidas por uma camada de cutícula de suberina (Fig. $5 a$ e 5b), que de acordo com Esau (1998), é extremamente resistente aos micro-organismos, proporcionando proteção mecânica e contra infecção por patógenos.

Os estômatos são tetracíticos, pois apresentam quatro células subsidiárias de contornos poligonais e tamanhos variados, e estão situados exclusivamente na face abaxial da folha, caracterizando-a como hipoestomática. Eles estão em grande quantidade e dispostos no mesmo nível das demais células da epiderme, assim como M. urundeuva (Silva et al., 2011), apresentando estrias laterais partindo de suas células-guarda (Fig. 5d). Esse tipo de estria não foi observado em M. urundeuva (Silva et al., 2011) e L. molleoides (Dias-Pereira et al., 2013).

Neste estudo, foram encontrados aproximadamente 370 estômatos por $\mathrm{mm}^{2}$. Taiz \& Zeiger (2009) explicam que a ausência de estômatos e cloroplastos na epiderme adaxial facilita a difusão interna, a absorção de $\mathrm{CO}_{2}$ e a passagem de luz para os tecidos subjacentes, aumentando a eficiência fotossintética. Além disso, a maior parte da transpiração foliar ocorre através do poro estomático, já que a cutícula é quase impermeável à água (Esau, 1998); dessa forma, o maior número de estômatos resulta num maior controle de perda de água por transpiração.

A aroeira-vermelha apresenta vários aspectos anatômicos foliares encontrados em xerófitas. As camadas múltiplas da epiderme na face adaxial foliar protegem o mesófilo de excessiva dessecação, bem como a presença de cutícula espessa (Fahn \& Cutler, 1992), como ocorre em outras espécies de ambientes semiáridos (Dickson, 2000). A presença de estômatos em grande quantidade também é uma característica compartilhada pela maioria das plantas de ambientes secos, a exemplo de M. urundeuva (Silva, 2011) e Agave sisalana Perrine (Cunha Neto \& Martins, 2012). De acordo com Dickison (2000), as folhas dessas plantas contêm geralmente um número bem maior de estômatos que outros tipos de plantas devido a necessidade de controlar a transpiração.

As folhas são isolaterais, pois em ambas as faces do mesofilo há a presença de parênquima paliçádico, que apresenta células delgadas, alongadas e regulares, dispostas perpendicularmente à superfície do limbo (Fig. 6). O parênquima paliçádico da face abaxial apresenta uma camada, com células menores e mais irregulares que o da face adaxial, que apresenta 2-3 camadas (Fig. 6 ), onde a primeira possui células mais largas $e$ com menos cloroplastos que a segunda (Fig. 6b). Comumente são encontradas drusas, tanto no parênquima paliçádico da face abaxial quanto no da face adaxial (Figs. 4b e 6a), de forma semelhante às encontradas no caule. $O$ mesofilo apresenta 5-8 faixas de parênquima lacunoso assimétrico denso, localizado entre as camadas de parênquima paliçádico; as células são irregularmente distribuídas e de formatos variados (Fig. 6a).

Anervura central da folha é biconvexa, sendo mais pontiaguda na face adaxial e acompanhando a formação dos canais secretores. O feixe vascular é descontínuo e dispõe-se de forma a isolar uma região de parênquima medular (Fig. 7). Existem
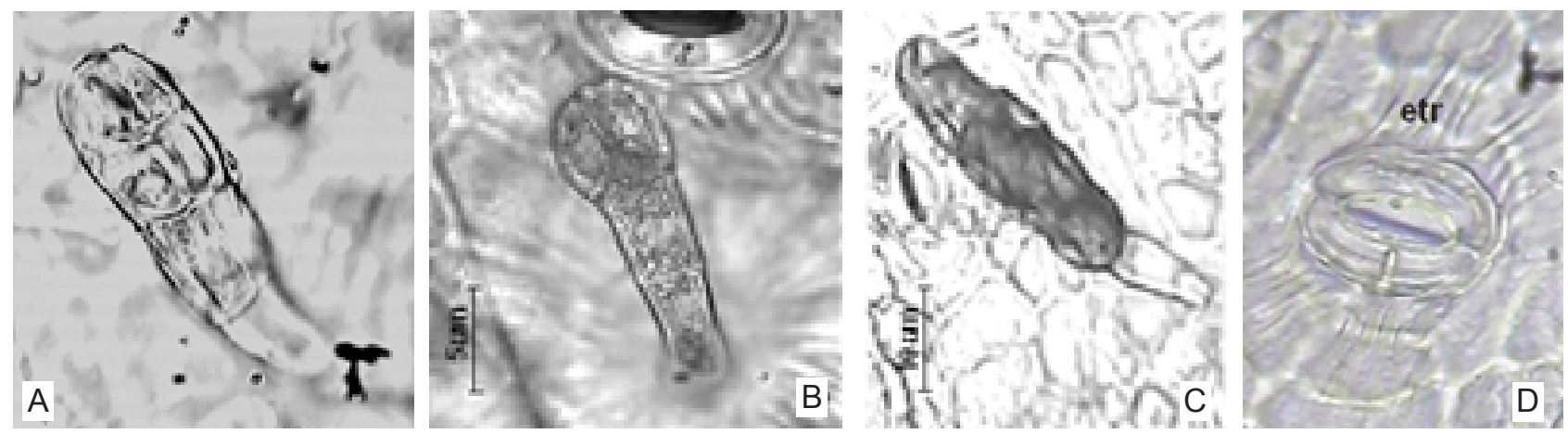

FIGURA 5. Schinus terebinthifolius Raddi, Anacardiaceae. Secções paradérmicas de folhas. a, b e c. epiderme abaxial evidenciando tricomas glandulares. d. epiderme abaxial evidenciando estômato tetracítico com estrias. (etr) estrias.

Rev. Bras. PI. Med., Campinas, v.17, n.1, p.26-35, 2015. 
de 7-10 camadas de colênquima acompanhando o feixe nas duas faces, após as epidermes abaxial e adaxial. O parênquima cortical periférico é escasso. Existem geralmente de 4-5 canais secretores grandes na região do floema de cada feixe vascular (Fig. 7), que apresentam características celulares semelhantes aos canais presentes no caule. São encontradas fileiras de parênquima partindo da periferia do feixe, e alternando-se com os canais secretores e os tecidos floema e xilema, até a parte central. Também é observada grande quantidade de drusas em toda a extensão da nervura central, principalmente próximo ao xilema. O floema é seguido internamente por feixes de xilema bem desenvolvidos, dispostos em fileiras, podendo algumas vezes estar separados por raios bem estreitos de células parenquimáticas. Também são encontradas células esclerenquimáticas dando sustentação ao feixe vascular. Para Apezzato-daGlória \& Carmelo-Guerreiro (2003), o padrão de nervuras encontrado na aroeira-vermelha tem a vantagem de extensibilidade e essa característica permite que os elementos de vaso se diferenciem em tecidos que estão crescendo, já que podem se alongar e continuar funcionais, levando água até as partes jovens da planta.
Na maioria das espécies, o floema está voltado para a face abaxial e o xilema está voltado para a face adaxial no feixe vascular da nervura central, em continuidade com esses tecidos no caule (Esau, 1998). Porém, na aroeira-vermelha, o xilema está disposto radialmente para a parte interna do feixe, e o floema também está disposto radialmente, mas para o lado externo, onde estão localizados os canais secretores bem desenvolvidos. Essas características também foram visualizadas em outras Anacardiáceas, como Anacardium occidentale L. (Jorge, 1996), Spondias tuberosa Arruda (Nascimento-Silva \& Paiva, 2007), M. urundeuva (Silva et al., 2011) e L. molleoides (Dias-Pereira et al., 2013).

A nervura secundária também é biconvexa, sendo mais pontiaguda na face adaxial, porém esta apresenta disposição de tecidos relativamente mais simples (Fig. 8a). São encontradas 3-5 camadas de colênquima seguindo as epidermes abaxial e adaxial, que são cobertas por cutícula. O xilema está voltado para a face adaxial, disposto geralmente em cinco raios principais, com células parenquimáticas entre eles (Fig. 8a). $\mathrm{Na}$ região do floema é encontrado um ducto secretor,
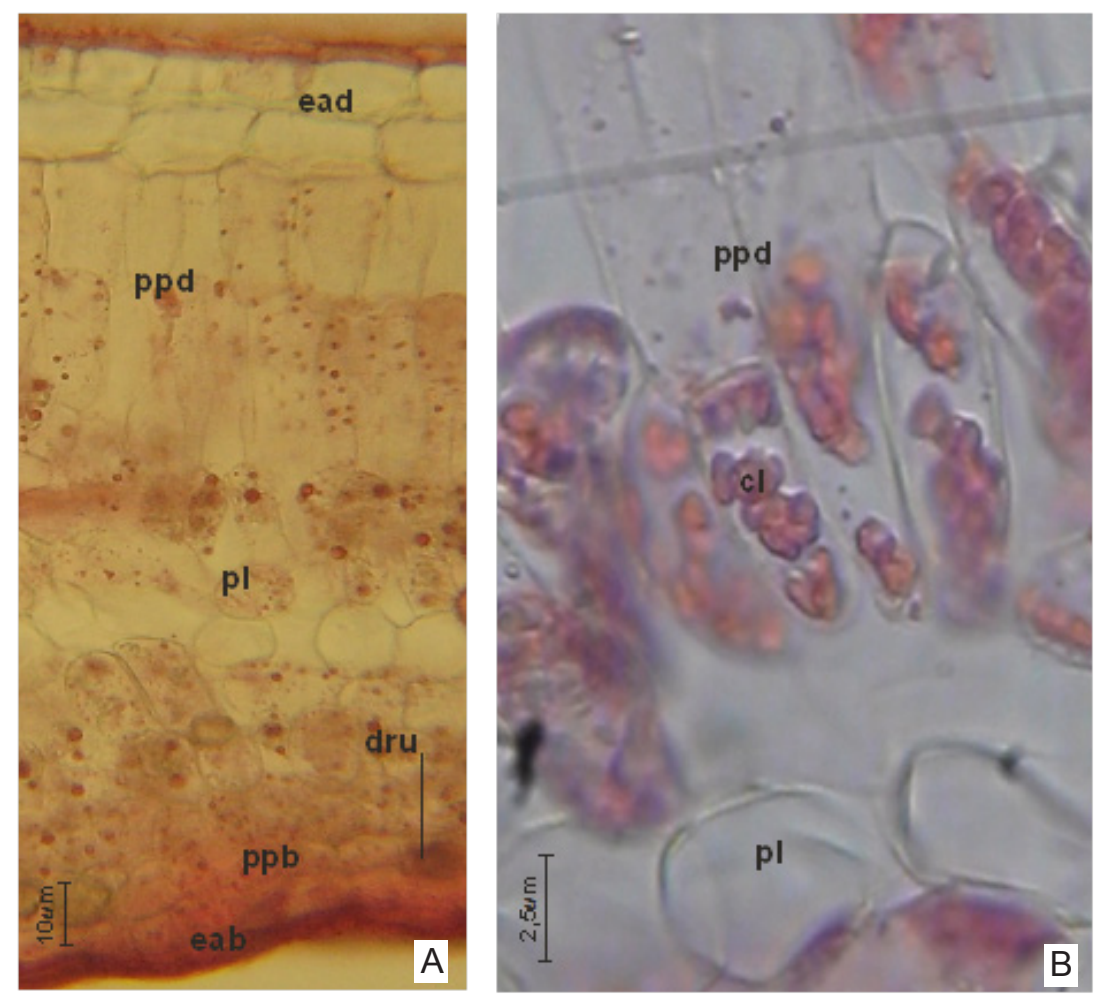

FIGURA 6. Schinus terebinthifolius Raddi, Anacardiaceae. Secções transversais da lâmina foliar. a. aspecto geral da lâmina foliar mostrando mesofilo isolateral. b. lâmina foliar evidenciando grande quantidade de cloroplastos na segunda camada do parênquima paliçádico da face adaxial. (ead) epiderme adaxial; (ppd) parênquima paliçádico da face adaxial; (pl) parênquima lacunoso; (dru) drusa; (ppb) parênquima paliçádico da face abaxial; (eab) epiderme abaxial; (cl) cloroplastos. 


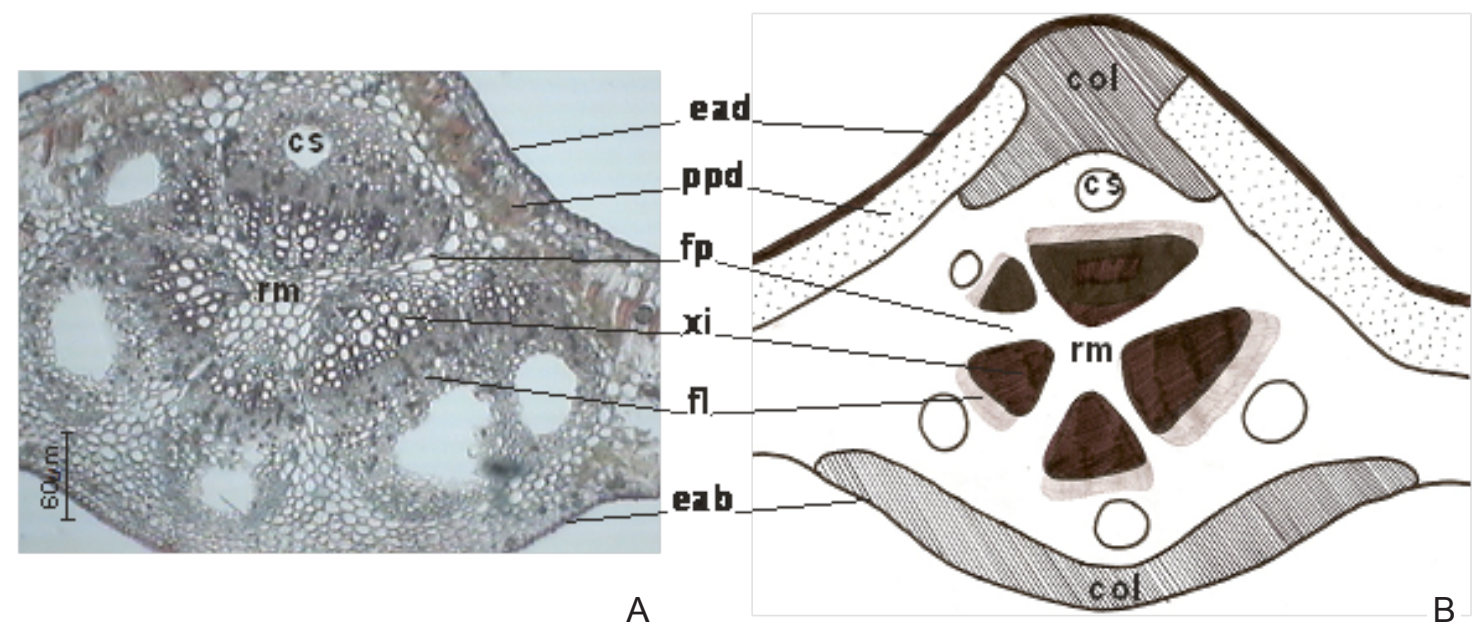

FIGURA 7. Schinus terebinthifolius Raddi, Anacardiaceae. Secção transversal da nervura central. a. fotomicrografia da organização geral mostrando feixe vascular isolando região de parênquima medular. $\mathbf{b}$. diagrama esquemático demonstrando nervura biconvexa e disposição dos tecidos. (ead) epiderme adaxial; (cs) canal secretor; ( $\mathbf{r m}$ ) região medular; (ppd) parênquima paliçádico da face adaxial; (fp) feixes de parênquima; (xi) xilema; (fl) floema; (eab) epiderme abaxial; (col) colênquima.

com características celulares semelhantes aos já descritos em outros locais da planta. É visualizada também uma quantidade moderada de esclerênquima irregularmente distribuído dando sustentação ao feixe (Fig. 8a). Existem drusas de oxalato de cálcio por todo o feixe vascular da nervura secundária, assim como na nervura central, porém em menor quantidade.

O pecíolo, em secção transversal, apresenta forma aproximadamente circular, com algumas ondulações acompanhando a disposição dos canais secretores (Fig. 8b). A epiderme é unisseriada e está coberta por cutícula. As células epidérmicas são arredondadas e apresentam muitos tricomas semelhantes aos encontrados no caule. Abaixo da epiderme encontra-se o parênquima cortical, constituído por 2-3 camadas de células isodiamétricas, e mais internamente, 3-5 camadas de parênquima clorofiliano, onde logo abaixo se têm 3-4 camadas de colênquima angular e após,
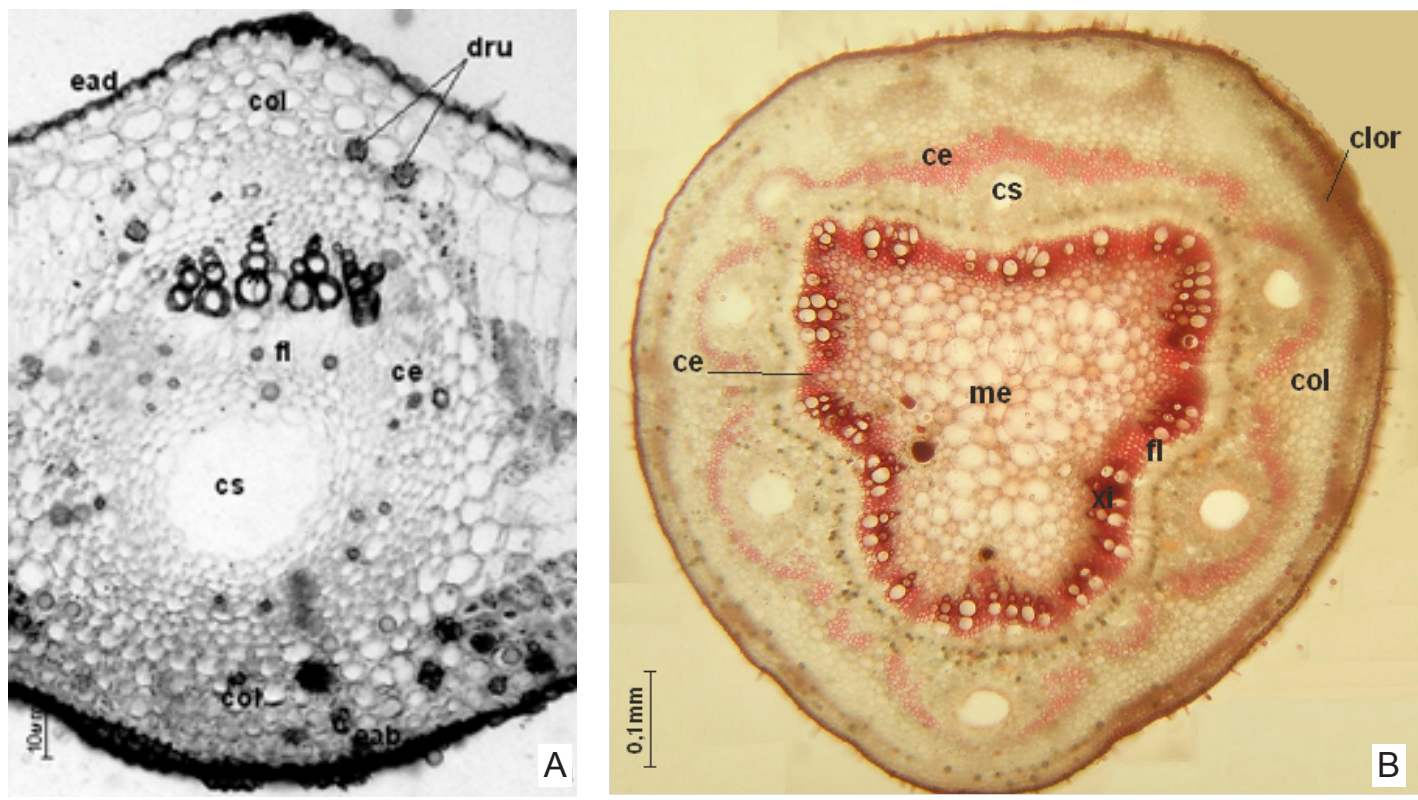

FIGURA 8. Schinus terebinthifolius Raddi, Anacardiaceae. a. Secção transversal da nervura secundária organização geral dos tecidos. b. Secção transversal do pecíolo. (ead) epiderme adaxial; (col) colênquima; (dru) drusa; (xi) xilema; (fl) floema; (ce) células esclerenquimáticas; (cs) canal secretor; (eab) epiderme abaxial; (cut) cutícula; (clor) clorênquima; (me) medula. 
camadas variáveis e irregulares de esclerênquima circundando todo o cilindro central.

O cilindro vascular do pecíolo é uniforme. Existem canais secretores bem desenvolvidos e circulares, distribuídos ao redor do cilindro vascular; esses canais situam-se no floema e apresentam as mesmas estruturas celulares já descritas para outras partes da planta. O floema situa-se externamente ao xilema, caracterizando um feixe vascular colateral. O xilema está distribuído em forma de raios, onde são encontrados feixes de esclerênquima. A cada quatro ou cinco raios xilemáticos há a presença de um raio estreito de células parenquimáticas. São encontradas drusas de oxalato de cálcio em pequenas quantidades, distribuídas irregularmente pelo parênquima cortical e próximo ao xilema. A medula está localizada na parte central do pecíolo e é formada por células parenquimáticas de tamanhos diferentes, as quais apresentam formatos que variam desde ovoides a triangulares.

Esau (1998) mostra que nas folhas pecioladas de várias espécies, o número e arranjo dos feixes vasculares no pecíolo e na nervura central variam grandemente e que as nervuras laterais são formadas geralmente por um único feixe, no qual o tecido vascular diminui em quantidade, a partir da formação da nervura lateral em direção às últimas ramificações. Essas duas condições são encontradas na aroeira-vermelha.

A descrição dos caracteres morfoanatômicos das partes aéreas vegetativas de $S$. terebinthifolius contribui fornecendo dados complementares para a caracterização da espécie. Os canais secretores bem desenvolvidos e a organização do feixe vascular na folha são importantes para a diferenciação da família, já que tais estruturas ocorrem também em outras anacardiáceas. Caracteres como epiderme bisseriada na face adaxial, estrias epidérmicas partindo das células-guarda podem auxiliar na sua diferenciação em relação às outras espécies conhecidas como aroeira. Além disso, a aroeiravermelha apresenta alguns aspectos estruturais característicos de plantas de ambientes secos, como camadas múltiplas da epiderme, presença de cutícula espessa e de drusas de oxalato de cálcio e grande quantidade de pelos e de estômatos, além de sistema vascular bem desenvolvido, com abundância de esclerênquima.

\section{REFERÊNCIAS}

AMORIM, M.M.R.; SANTOS, L.C. Tratamento da vaginose bacteriana com gel vaginal de Aroeira (Schinus terebinthifolius Raddi): ensaio clínico randomizado. Revista Brasileira de Ginecologia e Obstetrícia, v.25, n.2, p.95-102, 2003.
APEZZATO-DA-GLÓRIA, B.; CARMELLO-GUERREIRO, S.M. Anatomia Vegetal. Viçosa: UFV, 2003. 438p.

BARBOSA, L.C.A. et al. Seasonal variation in the composition of volatile oils from Schinus terebinthifolius Raddi. Química Nova, v. 30, n. 8, p. 1959-1965, 2007.

BARROSO, G.M.; PEIXOTO, A.L.; ICHASO, C.L.F.; GUIMARÃES, E.F.; COSTA, C.G. Sistemática de Angiospermas do Brasil. 2.ed. Viçosa: UFV, 2004. 309p.

BHATT, J.R.; MOHAN-RAM, H.Y. Development and ultrastructure of primary secretory ducts in the stem of Semecarpus anacardium (Anacardiaceae). IAWA Bulletin, v.13, p.173-185, 1992.

CARMELLO-GUERREIRO, S.M.; PAOLI, A.A.S. Morfologia e anatomia da semente de Schinus terebinthifolius Raddi (Anacardiaceae) em desenvolvimento. Revista Brasileira de Botânica, v.22, n.1, p.91-98, 1999.

CARMELLO-GUERREIRO, S.M.; PAOLI, A.A.S. Estrutura do Pericarpo e da Semente de Astronium graveolens Jacq. (Anacardiaceae) com Notas Taxonômicas. Revista Brasileira de Botânica, v.23, n.1, p.91-98, 2000.

CARMELLO-GUERREIRO, S.M.; PAOLI, A.A.S. Ontogeny and Structure of the Pericarp of Schinus terebinthifolius Raddi (Anacardiaceae). Brazilian Archives of Biology and Technology, v.45, n.1, p.73-79, 2002.

CARMELLO-GUERREIRO, S.M.; PAOLI, A.A.S. Anatomy of the pericarp and seed-coat of Lithraea molleoides (Vell.) Engl. (Anacardiaceae) with taxonomic notes. Brazilian Archives of Biology and Technology, v.48, n.4, p.599-610, 2005.

CERUKS, M. et al. Constituintes fenólicos polares de Schinus terebinthifolius Raddi (Anacardiaceae). Química Nova. v. 30, n. 3, p. 597-599, 2007.

CUNHANETO, I.L.; MARTINS, F.M. Anatomia dos órgãos vegetativos de Agave sisalana Perrine ex En-Gelm (Agavaceae). Revista Caatinga, v. 25, n. 2, p. 72-78, 2012.

DEGÁSPARI, C.H. et al. Atividade antimicrobiana de Schinus terebenthifolius Raddi. Ciência Agrotécnica, v. 29, n. 3, p. 617-622, 2005.

DIAS-PEREIRA, J. et al. Avaliações morfológicas e micromorfométricas de folhas de sol e de sombra de Lithraea molleoides (Vell.) Engl. (Anacardiaceae). Evolução e Conservação da Biodiversidade. v. 4, n. 1, p. 22-31, 2013.

DICKISON, W.C. Integrative Plant Anatomy. San Diego: Academic Press, 2000. 533p.

DUARTE, M.R. et al. Anatomia foliar comparada de espécies de aroeira: Myracrodruon urundeuva e Schinus terebinthifolius. Visão Acadêmica, v. 10, n. 1, p. 18-28, 2009.

ESAU, K. Anatomia das plantas com sementes. São Paulo: Edgard Blücher, 1998. 296p.

FAHN, A.; CUTLER, D.F. Xerophytes. Berlin: Gebruder Borntraeger, 1992. 176p.

FAHN, A. Structure and function of secretory cells. Advances in Botanical Research. v.31, p.37-75, 2000.

FENNER, R. et al. Plantas utilizadas na medicina popular brasileira com potencial atividade antifúngica. Revista Brasileira de Ciências Farmacêuticas. v. 42, n. 3, p. 369-394, 2006.

GOMES, F.S. et al. Antimicrobial lectin from Schinus terebinthifolius leaf. Journal of Applied Microbiology,

Rev. Bras. PI. Med., Campinas, v.17, n.1, p.26-35, 2015. 
v. 114, n. 3, p. 672-679, 2013.

JOHANN, S. et al. Inhibitory effect of extracts from Brazilian medicinal plants on the adhesion of Candida albicans to buccal epithelial cells. World Journal of Microbiology and Biotechnology. v. 24, n. 11, p. 2459-2464, 2008.

JORGE, L.I.F. et al. Diagnose laboratorial dos frutos e folhas de Anacardium occidentale L. (cajú). Revista Brasileira de Farmacognosia, n.1, p. 55-69, 1996.

KHAN, M.T.H. Natural Products as Potential Resources for Antifungal Substances: A Survey. Antifungal Metabolites from Plants. In: RAZZAGHI-ABYANEH, M.; MAHENDRA, R. Berlin: Springer, 2013. p. 157-165.

LACCHIA, A.P.S.; CARMELLO-GUERREIRO, S.M. Aspectos ultra-estruturais dos canais secretores em órgãos vegetativos e reprodutivos de Anacardiaceae. Acta Botânica Brasílica, v.23, n.2, p.376-388, 2009.

LARROSA, C.R.R.; DUARTE, M.R. Contribuição ao estudo anatômico do caule de Himatanthus sucuuba (Spruce ex Müll. Arg.) Woodson, Apocynaceae. Revista Brasileira de Farmacognosia, v.15, n.2, p.110-114, 2005.

LORENZI, H.; MATOS, F.J.A. Plantas Medicinais no Brasil: nativas e exóticas. 2.ed. Nova Odessa: Instituto Plantarum, 2008. 577p.

LORENZI, H. Árvores brasileiras: manual de identificação e cultivo de plantas arbóreas nativas do Brasil. v.1. 5.ed. Nova Odessa: Instituto Plantarum, 2008. 384p.

MACHADO, J.A. et al. In vitro evaluation of the antimicrobial potential association of Schinus terebinthifolius Raddi and Syzygium aromaticum L. Journal of Pharmacy. v.2, n. 3, p. 438-443, 2012

MACHADO, S.R.; CARMELLO-GUERREIRO, S.M. Estrutura e desenvolvimento de canais secretores em frutos de Schinus terebinthifolius Raddi (Anacardiaceae). Acta Botânica Brasileira, v.15, n.2, p.189-195, 2001.

MALIK, M.S. et al. Studies on the essential oil of Schinus terebinthifolius. Science International. v. 6, n. 4, p. 351-352, 1994.

MARTINS, E.R.; CASTRO, D.M.; CASTELLANI, D.C.; DIAS, J.E. Plantas Medicinais. 1.ed. Viçosa: Editora UFV, 2000. 220p.

MATSUO, A.L. et al. a-Pinene isolated from Schinus terebinthifolius Raddi induces apoptosis and confers antimetastatic protection in a melanoma model. Biochemical and Biophysical Research Communications. v. 411, n. 2, p. 449-454, 2011.

MEDEIROS, K.C.P. et al. Effect of the activity of the Brazilian polyherbal formulation: Eucalyptus globulus Labill, Peltodon radicans Pohl and Schinus terebinthifolius Radd in infl ammatory models. Revista Brasileira de Farmacognosia. v. 17, n.1, p. 23-28, 2007.

MOREIRA-CONEGLIAN, I.R., OLIVEIRA, D.M.T. Anatomia comparada dos limbos cotiledonares e eofilares de dez espécies de Caesalpinioideae (Fabaceae). Revista Brasileira de Botânica, v.29, n.2, p.193-207, 2006.

NASCIMENTO-SILVA, O.; PAIVA, J.G.A. Estudos morfológicos e anatômicos em folhas adultas de Spondias tuberosa Arruda (Anacardiaceae Lindley). Boletín Latinoamericano y del Caribe de Plantas Medicinais y Aromáticas, v.6, n.2, p. 36-43, 2007.

PAIVA, P.M.G.; GOMES, F.S.; NAPOLEÃO, T.H.; SÁ, R.A.; CORREIA, M.T.S.; COELHO, L.C.B.B. Antimicrobial activity of secondary metabolites and lectins from plants. In: MENDEZ-VILLAS, A. Current research, technology and education topics in applied microbiology and microbial biotechnology. Formatex Research Center: Espanha, 2010. p. 396-406.

QUEIRES, L.C. et al. In vitro effects of polyphenols extracted from the aroeira plant (Schinus terebinthifolius Raddi) on the growth of prostate cancer cells (Lncap, Pc-3 and Du145). Brazilian Journal of Medicine and Human Health, v. 1, n. 1, p. 71-82, 2013.

QUEIROZ, C.R.A.A. et al. Caracterização dos Taninos da aroeira-preta (Myracrodruon urundeuva). Revista Árvore, v.26, n.4, p. 485-492, 2002.

SANTOS, A.C.A. et al. Efeito fungicida dos óleos essenciais de Schinus molle L. e Schinus terebinthifolius Raddi, Anacardiaceae, do Rio Grande do Sul. Revista Brasileira de Farmacognosia. v. 20, n. 2, p. 154-159, 2010.

SANTOS, M.R.A. et al. Atividade inseticida do óleo essencial de Schinus terebinthifolius Raddi sobre Acanthoscelides obtectus Say e Zabrotes subfasciatus Boheman. Boletim de Pesquisa e Desenvolvimento - Embrapa, v. 48, 13p, 2007.

SANTOS, M.R.A. et al. Composição química e atividade inseticida do óleo essencial de Schinus terebinthifolius Raddi (Anacardiaceae) sobre a broca-do-café (Hypothenemus hampei) Ferrari. Revista Brasileira de Plantas Medicinais, v. 15, n. 4, p. 757-762, 2013.

SILVA, O.N. et al. Morphology, anatomy and histochemistry of the leaves of Myracrodruon urundeuva Allemão (Anacardiaceae). Boletín Latinoamericano y del Caribe de Plantas Medicinales y Aromáticas. v. 10, n. 1, p. 56-66, 2011.

SOUZA, L.A. Morfologia e Anatomia Vegetal: células, tecidos, órgãos e plântulas. Ponta Grossa: Editora UEPG, 2003. 258p.

TAIZ, L.; ZEIGER, E. Fisiologia Vegetal. 4.ed. Porto Alegre: Artmed, 2009. 848p.

VARELA-BARCA, F.N.T. et al. Base excision repair pathway is involved in the repair of lesions generated by flavonoid-enriched fractions of pepper tree (Schinus terebinthifolius) stem bark. Environmental and Molecular Mutagenesis. v. 48, n. 8, p. 672681, 2007. 